\title{
8. BASEMENT LOGGING ON THE MID-ATLANTIC RIDGE, DEEP SEA DRILLING PROJECT HOLE 395A ${ }^{1}$
}

\author{
Mark Mathews, Los Alamos National Laboratory \\ Matthew H. Salisbury, Deep Sea Drilling Project, Scripps Institution of Oceanography \\ and \\ Roy Hyndman, Pacific Geoscience Centre, Department of Energy, Mines and Resources, Sidney, B.C. ${ }^{2}$
}

\begin{abstract}
On Leg 78B, the Glomar Challenger returned to Hole 395A on the Mid-Atlantic Ridge and logged the upper $0.5 \mathrm{~km}$ of the crust, obtaining excellent resistivity, natural-gamma, and caliper logs throughout the section and reasonable density and velocity logs near the base. The logs show that the crust may be divided into two distinct geophysical units. The upper $400 \mathrm{~m}$ of the crust displays high porosities and low velocities, densities and resistivities. Below this, between 400 and $500 \mathrm{~m}$ sub-basement, the crust displays a low crack porosity (1-2\%), high resistivities (up to $1000 \mathrm{\Omega m}$ ), and high velocities (up to $6.0 \mathrm{~km} / \mathrm{s}$ ). For the lower unit, a value of 2.2 was obtained for the exponent $m$ in Archie's Law, which is consistent with low permeabilities measured in the same interval with a packer ( 2 to $9 \mu$ darcies). Since the boundary between these two units is marked by a sharp increase in alteration products and the lower unit behaves as if it were sealed, we conclude that Hole 395A penetrated a major geophysical discontinuity.
\end{abstract}

\section{INTRODUCTION}

Since geophysical logging was first introduced by Conrad Schlumberger in 1927, numerous wells drilled by industry have been logged to refine the stratigraphy determined from cuttings and core descriptions; to provide a basis for comparing the physical properties of cores with surface geophysical measurements; and to provide a quantitative basis for evaluating reservoirs, first by identifying and measuring the porosity and permeability of production zones, and second, by conducting flow tests to estimate the production that may be expected from a well and the life of the reservoir.

Since the advent of the Deep Sea Drilling Project in 1968 , many of the logging techniques developed by industry have been applied in boreholes drilled in the ocean basins for scientific purposes. Although many DSDP sediment boreholes have been logged (e.g., Montadert, Roberts, et al., 1979; Boyce, 1980; Yeats, Haq, et al., 1981; Curray, Moore, et al., 1982), before Leg 78B only five serious attempts were made to log holes drilled in oceanic basement: Hole 396B on the Mid-Atlantic Ridge (Kirkpatrick, 1979); Hole 417D on the Bermuda Rise (Salisbury, Donnelly, et al., 1980; Salisbury, Stephen, et al., 1980); Hole 462A in the Nauru Basin (Boyce, 1981); Holes 482C, 483, and 485A in the mouth of the Gulf of California (Salisbury, 1983); and Hole 504B on the Costa Rica Rift (Cann and Von Herzen, 1983). Of these, several were in anomalous crust. The igneous section logged in Hole 462A consisted of a massive sill complex associated with mid-plate volcanism. The sections logged

\footnotetext{
${ }^{1}$ Hyndman, R. D., Salisbury, M. H., et al., Init. Repts. DSDP, 78B: Washington (U.S. Govt, Printing Office).

2 Addresses: (Mathews) Los Alamos National Laboratory, Los Alamos, NM 87545; (Salisbury) Deep Sea Drilling Project, Scripps Institution of Oceanography, La Jolla, CA; (Hyndman) Pacific Geoscience Centre, Dept. of Energy, Mines and Resources, Sidney, B.C., Canada.
}

on Leg 65 (Holes 482C, 483, and 485A) consisted of interlayered sediments and massive flows or sills deposited during the early rifting of the Gulf of California in an environment characterized by slow spreading and extremely rapid sediment accumulation. The only "typical" sections of ocean crust logged were a 552-m-thick section of young pillow basalts formed at an intermediate spreading rate on the Costa Rica Rift (Hole 504B) and two sections formed by slow spreading on the Mid-Atlantic Ridge: a 200-m-thick interval of young pillow basalts in Hole 396B and a 100-m-thick interval of rubble, pillow basalts, and massive basalts, dated Cretaceous, on the Bermuda Rise (Hole 417D).

One of the principal objectives of Leg 78B was to log Hole 395A, a 571-m basement hole drilled in 7.2-Maold crust on the Mid-Atlantic Ridge during Leg 45, so as to obtain a set of reference logs through a thick section of young crust formed by slow spreading. Although equipped with a re-entry cone and cased to basement, the hole had never been logged.

As with industry logging, one of our purposes in logging Hole 395A was to refine the stratigraphy determined from coring. Although continuously cored, the recovery in basement averaged only $18 \%$, and large sections of the hole were represented by less than $5 \%$ recovery. Since the possibility of a serious recovery bias existed, with only the more competent rocks being recovered, and since there was an uncertainty of up to $9 \mathrm{~m}$ in the sampling depth whenever the core barrel was only partially filled, logs were needed to reconstruct the actual stratigraphy of the hole.

More important, downhole logs were needed to characterize the formation properties of the crust itself. Once logs have been calibrated through comparison with the physical properties of the core material (e.g., Mathews and LaDelfe, 1981), it is possible to determine the porosity, resistivity, density, and sonic velocity of the for- 
mation as a function of depth. In performing such calibrations it must be borne in mind that (1) the scales of investigation for laboratory studies and for logs are quite different; (2) the physical properties of the incompetent rock that cannot be successfully cored and recovered will affect the logging (and the surface geophysical measurements) more than the properties of the competent rock that can be recovered, so that core analysis can be misleading if only partial recovery is achieved; and (3) even the laboratory analyses themselves can be misleading, since removing a sample from its in situ conditions of temperature, water saturation, and effective confining pressure and then restoring it to these conditions in the laboratory for analysis may permanently alter its physical characteristics. It may not be possible to restore the sample to its original state, because of physical or chemical hysteresis effects. Despite these difficulties, it is often possible to obtain a reliable estimate of formation properties by comparing the results obtained with different tools; and the results are worth the effort. Independent evaluations of the porosity in the crust at several sites, for example, have led to the important conclusion that the uppermost level of the ocean crust is often extremely porous, ranging from 10 to $20 \%$ (Kirkpatrick, 1979; Salisbury, Stephen, et al., 1980; Becker et al., 1982).

Finally, the formation properties in Hole 395A were needed for comparison with surface geophysical measurements and the results of other experiments conducted in the same hole. In industry, comparisons with surface data are commonly made to adjust the vertical resolution of the surface geophysics and to help identify subsurface horizons. For example, the density-sonic data acquired from boreholes have been used to identify refracting and reflecting horizons and to convert seismic wave travel times to depths (Stone and Evans, 1980). In Hole 395A, one of our objectives was to compare the velocity $\log$ with the velocity structure determined by the DARPA borehole seismometer experiment (Ballard; Jacobsen et al.; Hyndman and Salisbury; all this volume) and the structure determined by surface refraction studies (Hussong et al., 1979; Kasahara et al., 1980). In addition, we hoped to compare the temperature log with regional heat-flow data (Hussong et al., 1979; Becker et al., this volume) and the porosity and caliper logs with the televiewer log (Hickman et al., this volume) and the results of packer tests (Hickman et al., this volume).

\section{LOGGING IN OCEANIC BASEMENT}

The interpretation of downhole logs in oceanic basement is, in principle, more straightforward than for logs in oil wells because the upper ocean crust is thought to be a relatively simple stratigraphic system. To a first approximation, the formation is made up of basalt with a limited compositional range and a formation fluid with the approximate composition of seawater contained in several types of porosity. The properties of the basalt matrix vary little within the commonly occurring range of composition, changing significantly only with pronounced low-temperature weathering or with hydrothermal alteration. Though locally important, neither of these processes is usually pervasive in young upper ocean crust. The composition of the pore fluid is probably close to that of seawater. Chemical interaction with the rocks will change the fluid composition, but the physical properties should remain similar to those of seawater. Table 1 gives typical laboratory physical property values for comparison with the physical properties commonly measured by downhole logs: compressional-wave velocity $\left(V_{p}\right)$, density $(\rho)$, and electrical resistivity $(R)$ (see Christensen and Salisbury, 1975; Hyndman and Drury, 1976; Schreiber and Rabinowitz, 1979; Melson, Rabinowitz, et al., 1979).

Thus, the log responses and the physical properties of the formation will depend first on variations in the proportions of basalt and water (i.e., on the porosity) and second on the form of the porosity, particularly the degree to which it is interconnected. [Only to a much lesser degree do the mechanical $(\Delta t)$ or electrical log responses depend on the matrix composition. At the present time it is not known how much the nuclear log responses (especially the neutron log) depend on the matrix composition.] The formation porosity occurs principally in two forms:

1. In small-scale vesicles and along grain boundaries (some water is also held in smectite clays). This smallscale porosity averages 5 to $10 \%$, and is the component measured in core samples. It is generally poorly connected, so that the permeability of core samples is low, about $10^{-18} \mathrm{~m}^{2}(\approx 1 \mu$ darcy); (Hamano, 1980; Johnson, 1980). $\left(10^{-12} \mathrm{~m}^{2} \approx 1\right.$ darcy.)

2. In large-scale porosity in the form of fractures, drained lava pillows and tubes, flow breccias, talus, and rubble. It is this component that has made deep drilling into young ocean crust difficult. The large-scale porosity is probably of irregular distribution, but is well connected and gives the ocean crust its apparently high permeability (Hickman et al., this volume; Becker et al., this volume). This porosity occurs on a scale of centimeters to meters, and will not be observed or measured in core samples, but generally will be observed in the logs.

The response of all standard logs should correlate with porosity, but the degree to which the various log responses

Table 1. Typical physical property values for unaltered basalt and seawater at $0.2 \mathrm{~kb}, 10^{\circ} \mathrm{C}$.

\begin{tabular}{|c|c|c|c|}
\hline & $\begin{array}{c}\text { Compressional- } \\
\text { wave velocity }{ }^{\mathrm{a}} \\
\left(V_{p}\right) \\
(\mathrm{km} / \mathrm{s})\end{array}$ & $\begin{array}{c}\text { Density } \\
(\rho) \\
\left(\mathrm{g} / \mathrm{cm}^{3}\right.\end{array}$ & $\begin{array}{c}\text { Resistivity } \\
(R) \\
(\mathrm{g})\end{array}$ \\
\hline Basalt $^{\mathrm{c}}$ & 6.0 & 2.9 & 200 \\
\hline Basalt matrix ${ }^{\mathrm{d}}$ & 6.4 & 2.95 & $>10^{4}$ \\
\hline Seawater & 1.5 & 1.05 & 0.3 \\
\hline \multicolumn{4}{|c|}{$\begin{array}{l}\text { a At low confining pressures, } V_{p} \text { increases rapidly with in- } \\
\text { creasing pressure and decreases slowly with increasing } \\
\text { temperature. } \\
\text { b The resistivity of seawater and thus of core samples de- } \\
\text { creases rapidly with increasing temperature. } \\
\text { c Grain boundary plus vesicular porosity totals } 5-10 \% \text {. } \\
\text { d Zero porosity. }\end{array}$} \\
\hline
\end{tabular}


are sensitive to pore structure or the degree of interconnection should vary considerably, as follows:

1. Gamma-gamma density: generally insensitive to pore structure and the degree of interconnection; this measurement is a volume-statistical measurement affected by the total porosity.

2. Neutron-thermal-neutron porosity: generally insensitive to pore structure and the degree of interconnection; this measurement is a volume-statistical measurement affected by hydrogen, matrix elements, the amount of chlorine present (thermal-neutron absorbers), and the total porosity.

3 . Velocity $(\Delta t)$ : moderately sensitive to pore structure and the degree of interconnection. This measurement is basically a mechanical properties measurement and in theory, the normal (compressional-wave) interval transit time is little affected by voids, vugs, or fractures, so long as there is a free matrix path between the transmitter and the receivers (as would be expected for voids, gas bubbles, cavities in pillow basalts, and vertical fractures). On the other hand, the shear-wave energy and amplitude are strongly affected. The velocity measurement should be influenced more by effective (interconnected) porosity than by total porosity.

4. Resistivity: very sensitive to pore structure and the degree of interconnection. This dependency varies with the type of resistivity device used. Normally the induction log ignores vertical voids and fractures, but is somewhat sensitive to horizontal voids and fractures. Latero$\log$ (guard log) devices are affected in two ways. A continuous water-filled pore structure (voids, fractures, etc.) short-circuits the current lines and lowers the resistivity. But in a low-porosity matrix, the conductivity network is generally very small to microscopic, or limited to fracture zones which are largely unidirectional. Either way, these conditions tend to increase the apparent resistivity significantly, and are a function of the effective porosity.

The differences between the porosity estimates derived from the different logs give a qualitative indication of the degree of pore interconnection, and thus of the formation permeability. The analysis required to understand the form of the porosity is similar to reservoir analysis in the petroleum industry.

There are two serious difficulties, however, with logs in oceanic basement holes and with their analysis. First, no mud is used in basement drilling, and the holes are frequently out of gauge and washed out. This problem is exacerbated by the requirement that the tools must pass through a small-diameter drill pipe and then open into a very large-diameter borehole. Second, relatively little is known about the responses of the various types of logs and specific logging tool configurations to basalt and to the type of formation observed in the upper oceanic crust. We shall further discuss these difficulties.

\section{Borehole Conditions in Hole 395A}

Hole 395A was drilled between 9 December 1975 and 9 January 1976 at $22^{\circ} 45.35^{\prime} \mathrm{N}, 76^{\circ} 04.90^{\prime} \mathrm{W}$ at a water depth of $4485 \mathrm{~m}$ (sea level). The top of the basement was encountered at a depth of $4578 \mathrm{~m}$, or $93 \mathrm{~m}$ below the ocean floor. A re-entry cone was set and a $29.85-\mathrm{cm}$ $\left(11^{3 / 4}\right.$-in.) casing was set from the ocean floor to a depth of $4597 \mathrm{~m}$, or $19 \mathrm{~m}$ into the basement. The borehole was cored from $4579 \mathrm{~m}$ to approximately $5149 \mathrm{~m}$ with a 22.23 -cm (83/4-in.) bit. Core recovery was $19 \%$; aphyric basalt represented $58 \%$ of the material recovered, phyric basalt $31 \%$, basalt breccias $7 \%$, and intrusive dolorites $4 \%$. The lithologic summary for the hole is given in Table 2.

Like most DSDP holes, Hole 395A was drilled with only salt water as the drilling fluid. A slug of fresh water and bentonite mud was put in the hole at the completion of drilling, but borehole fluid samples taken near the base of the hole before the logging consisted essentially of seawater, except at the very bottom of the hole, where some mud may have remained (McDuff, this volume). Seawater has a very high electrical conductivity (approximately $4000 \mathrm{~m} \mathrm{mho} / \mathrm{m}$ or $0.25 \mathrm{ohm}-\mathrm{m}$ ), which limits the types of electrical logs that will operate properly to focused electrical tools. The electric fields or currents of self potential of most induction and some laterolog resistivity logs are lost or blocked by the high-conductivity fluid in the borehole. Also, because the borehole fluid has nearly the same conductivity as the formation pore fluid, permeability estimates based on the depth of invasion of the drilling fluid (which is derived from the difference in response of shallow and deep investigating tools) cannot be used.

Finally, since no mud or borehole conditioner was used during drilling, it was anticipated that the walls of the hole would display considerable rugosity and numerous washouts, which would severely affect the responses of some logs. The two-arm caliper log depicts a very rough hole that is generally $28 \mathrm{~cm}$ (11 in.) or larger in diameter and in some places is washed out to greater than $48 \mathrm{~cm}$ (19 in.), the maximum extension of the caliper tool. Since the standard API borehole is $20 \mathrm{~cm}$ (77/8 in.), Hole 395A is considered a large-diameter hole. Most standard logging tools are not designed for this larger diameter, even excluding the washouts, and give poor and inaccurate responses under such conditions. Diameter correction curves for such large-diameter holes are available for some tools, however.

A final special problem of logging from the Glomar Challenger is ship heave and the resulting vertical oscillation of the logging tools. No heave compensation was used on the logging cable. Although sea conditions were calm, ship heave was on the order of a meter. Close examination of the logs run at the slower speeds suggests occasional repetition of sharp features over short distances, implying tool oscillations also of the order of a meter.

\section{LOGGING TOOLS USED}

The logging tools made available by Gearhart-Owen for use in Hole 395A were the natural gamma-ray, sonic ( $\Delta T$ only), gamma density, neutron (thermal), guard resistivity, temperature, two-arm caliper, and four-arm $(X-Y)$ caliper tools. Two or more logs are normally run on one lowering. All the tools were less than the $35 / 8-i n .(9.2-\mathrm{cm})$ diameter limitation imposed by the $315 / 16-$ in. $(10-\mathrm{cm})$ minimum diameter restriction in the pipe after the bit has been released. The tools have a 
Table 2. Lithologic summary, Hole 395A. ${ }^{a}$

\begin{tabular}{|c|c|c|c|c|c|}
\hline $\begin{array}{l}\text { Lithologic } \\
\text { Unit }\end{array}$ & $\begin{array}{l}\text { Chemical } \\
\text { Unit }\end{array}$ & Lithology & Cores & $\begin{array}{l}\text { Inferred sub-bottom } \\
\text { interval (m) and } \\
\text { thickness (in paren.) }\end{array}$ & Distinguishing characteristics \\
\hline 1 & & Sedimentary breccia & $3-5$ & $87.60-110.79(23.19)$ & $\begin{array}{l}\text { Sub-rounded to angular fragments of aphyric basalt, and ultramafic to mafic } \\
\text { plutonic rocks in foraminifer-nannofossil ooze }\end{array}$ \\
\hline 2 & $\mathbf{A}_{2}$ & Aphryic basalt & $5-13$ & $110.79-172.44(61.65)$ & Aphyric pillow basalt \\
\hline 3 & & Sedimentary breccia & 13 & $172.44-174.31(1.87)$ & Two sub-angular fragments of serpentinite, $1 \mathrm{pc}$. aphyric basalt \\
\hline 4 & $\mathrm{P}_{2}$ & Phyric basalt & $13-16$ & $174.31-210.52(36.11)$ & Plagioclase-olivine phyric fine-grained massive basalt \\
\hline 5 & $\mathrm{P}_{3}$ & Phyric basalt & $17-22$ & $210.52-257.00(46.48)$ & Plagioclase-olivine-clinopyroxene phyric \\
\hline 6 & & Phyric basalt & 22 & $257.00-260.37(3.37)$ & $\begin{array}{l}\text { Plagioclase-olivine-clinopyroxene phyric with fewer plagioclase phenocrysts } \\
\text { than Unit } 5\end{array}$ \\
\hline 7 & $\mathrm{P}_{4}$ & Phyric basalt & $23-25$ & $260.37-288.79(28.42)$ & Plagioclase-olivine phyric with rare large clinopyroxene phenocrysts \\
\hline 8 & & Phyric basalt & 26-27 & $288.79-307.84$ (19.05) & Plagioclase-olivine clinopyroxene phyric \\
\hline 9 & & Phyric basalt & 28 & $307.84-317.34(9.50)$ & Plagioclase-olivine phyric \\
\hline 10 & & Phyric basalt & 29 & $317.34-326.87(9.53)$ & $\begin{array}{l}\text { Plagioclase-olivine-clinopyroxene phyric pieces and plagioclase-olivine } \\
\text { phyric pieces }\end{array}$ \\
\hline 11 & & Phyric basalt & 30 & $326.87-336.06(9.19)$ & Olivine-plagioclase phryic \\
\hline 12 & $P_{5}$ & Phyric basalt & 31 & $336.06-344.46(8.40)$ & $\begin{array}{l}\text { Mixed pieces plagioclase-olivine-clinopyroxene phyric and plagioclase- } \\
\text { olivine phyric }\end{array}$ \\
\hline 13 & & Basaltic breccia & 32 & $344.46-354.00(9.54)$ & $\begin{array}{l}\text { Angular clasts of fine- to medium-grained plagioclase-olivine phyric basalt } \\
\text { in carbonate clay-rich matrix; clasts include coarsest-grained basalt } \\
\text { found; evidence of hydrothermal alteration }\end{array}$ \\
\hline 14 & & Phyric basalt & 33 & $354.00-360.87(6.87)$ & $\begin{array}{l}\text { Mixed pieces plagioclase-olivine-clinopyroxene and plagioclase-olivine } \\
\text { phyric basalt }\end{array}$ \\
\hline 15 & & Hyaloclastite & 33 & $360.87-362.24(1.37)$ & Fine-grained basalt and basaltic glass in recrystallized carbonate ooze \\
\hline 16 & & Aphyric basalt & $33-49$ & $362.24-504.77(142.53)$ & Aphyric basalt with very rare rounded plagioclase "xenocrysts" \\
\hline 17 & $\mathbf{A}_{3}$ & Basaltic breccia & 49 & $504.77-508.74(3.97)$ & $\begin{array}{l}\text { Angular, brecciated fine- to medium-grained basalt clasts, including variolitic } \\
\text { rinds and altered glass clasts in clay-rich matrix }\end{array}$ \\
\hline 18 & b & Aphyric basalt & $49-58$ & $508.74-585.00(76.26)$ & $\begin{array}{l}\text { Aphyric basalt with rare olivine and plagioclase "xenocrysts," highly frac- } \\
\text { tured, abundant veins filled with secondary minerals }\end{array}$ \\
\hline 19 & $\mathrm{~A}_{4}$ & $\begin{array}{l}\text { Glass-rich basaltic } \\
\text { breccia and } \\
\text { aphyric basalt }\end{array}$ & $58-61$ & $585.00-608.10(23.10)$ & $\begin{array}{l}\text { Breccias with abundant basaltic glass marginally altered to numerous second- } \\
\text { ary minerals in a matrix of alteration products; some zones of aphyric } \\
\text { basalt with some glassy rinds with variolitic zones }\end{array}$ \\
\hline 20 & & Dolerite & 61 & $608.10-617.49(9.39)$ & Plagioclase-olivine-clinopyroxene basalt, medium-grained \\
\hline 21 & $\mathbf{P}_{4}$ & Aphyric basalt & 62 & $617.49-617.96(0.47)$ & $\begin{array}{l}\text { Thin zone of aphyric basalt with glassy and variolitic rind; surfaces sheared } \\
\text { and coated with clay and other secondary minerals }\end{array}$ \\
\hline 22 & & Dolerite & $62-64$ & $617.96-630.15(12.19)$ & $\begin{array}{l}\text { Plagioclase-olivine-clinopyroxene basalt, medium-grained; quenched contact } \\
\text { at base }\end{array}$ \\
\hline 23 & $\mathrm{~A}_{4}$ & $\begin{array}{l}\text { Aphyric basalt with } \\
\text { some glassy } \\
\text { breccia zones }\end{array}$ & $64-67+$ & $630.15-664.09+(33.94+)$ & $\begin{array}{l}\text { Aphyric basalt, glassy basaltic breccias, numerous glassy-variolitic rinds, } \\
\text { abundant soft light-colored clay in fractures; highly fractured }\end{array}$ \\
\hline
\end{tabular}

a From Melson, Rabinowitz, et al., 1979b.

b The boundary between Chemical Units $\mathrm{A}_{3}$ and $\mathrm{A}_{4}$ lies within Lithologic Unit 18 at a sub-bottom depth of $570.08 \mathrm{~m}$.

temperature rating of at least $150^{\circ} \mathrm{C}\left(300^{\circ} \mathrm{F}\right)$ and a pressure rating of at least $105 \mathrm{MPa}(15,000 \mathrm{psi})$. All the above logs except the four-arm caliper were run in Hole 395A. A brief description of each of the combination logging tools follows.

\section{Gamma Density, Two-Arm Caliper, Temperature, and Natural-Gamma Tools}

The first logging run was with a gamma-gamma density, two-arm caliper, high-resolution temperature, and natural-gamma combination tool (Fig. 1A). A gamma-ray scintillation detector [NaI(Tl)] is located in the upper portion of the tool. It records natural gamma rays, produced primarily from potassium, uranium, and thorium in the rock surrounding the borehole, but does not distinguish among the elements. The concentrations of these elements are normally quite low in oceanic basalts, so there is limited response. The log will be sensitive, however, to any alteration that concentrates these elements. Such concentrations tend to occur along fractures through which hydrothermal circulation is channeled. The natural-gamma log is usually run as part of each tool combination to provide an accurate depth reference on each logging run.

A gamma-gamma backscatter density tool is the second part of this probe. It has two $\mathrm{NaI}(\mathrm{Tl})$ scintillation detectors and a $7.4 \times 10^{4}$ $\mathrm{MBq}$ (2-Curie) ${ }^{137} \mathrm{Cs}$ gamma-ray source, all of which are collimated. $\left(1\right.$ Curie $=3.7 \times 10^{10} \mathrm{~Bq}$. $)$ The two detectors help compensate for invasion of drilling fluid and, to a limited extent, for borehole rugosity and the effects of the borehole fluid. The source and detectors are mounted on a skid held against the wall by a moveable arm. A backup or pressure arm is located on the opposite side of the tool. The arrangement also provides a two-arm caliper measurement. The detector-source skid must be held against the hole wall for good density data to be obtained. The device responds to the electron density of the formation, which is converted to bulk density. The ratio of the atomic number $Z$ to the atomic weight $A$ is usually assumed to be 0.5 in the conversion. The shipboard laboratory GRAPE density system employs the same principle as the logging device.

The high-resolution temperature probe employs a thermistor sensor with a time constant of a few seconds located in a cage at the bottom of the tool. The response can be slowed considerably if the cage is jammed with mud. It has a precision of $0.006^{\circ} \mathrm{C}\left(0.01^{\circ} \mathrm{F}\right)$ and a temperature range of 0 to $150^{\circ} \mathrm{C}\left(32-300^{\circ} \mathrm{F}\right)$. On-site calibration, at least with an ice bath, is required for reliable absolute temperatures. Valid formation temperatures can be obtained only if adequate time is allowed for the drilling thermal disturbance to decay, or through careful extrapolation to equilibrium, and if there is no water flow in the hole.

Satisfactory density, natural-gamma (although of very low amplitude), caliper, and temperature (although not equilibrium) data were obtained.

\section{Sonic and Natural Gamma-Ray Tools}

The second logging run was with a sonic, natural-gamma, and twoarm caliper combination tool (Fig. 1B). The gamma-ray detector is a Geiger-Müller (GM) tube, in contrast to the NaI(Tl) scintillation detector in the previous tool. It did not appear to give valid data on this run. The caliper operated in the borehole and centralized the upper part of the sonic tool, but the caliper size could not be recorded. The sonic probe is a standard borehole-compensated 3-2-3 probe with two transmitters and two receivers. It thus operates like a reversed seismic refraction experiment, the transit time recorded being the average transit time between the pair of receivers in each direction. The transmitters are at each end, and the receivers are in the middle with a spacing of $3 \mathrm{ft} .-2 \mathrm{ft} .-3 \mathrm{ft}$. The coventionally logged parameter is $\Delta t$ in $\mu \mathrm{s} / \mathrm{ft}$., which may be converted to $\mathrm{km} / \mathrm{s}$ by dividing 304.8 by the $\Delta t$ value. 


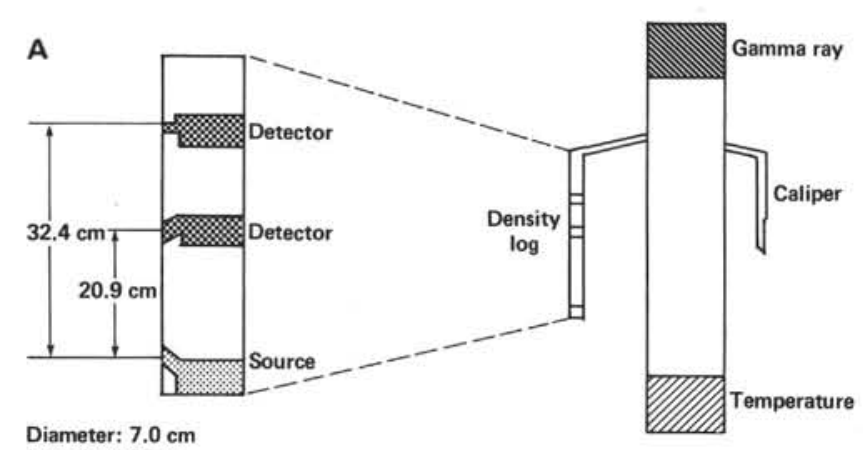

B

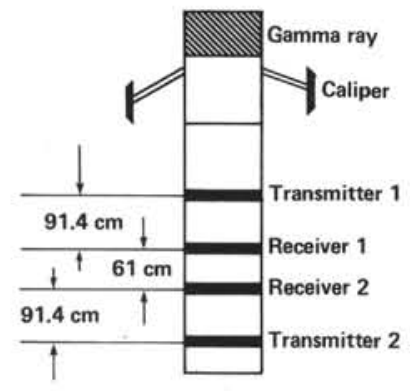

Diameter: $8.57 \mathrm{~cm}$ Length: $7.1 \mathrm{~m}$

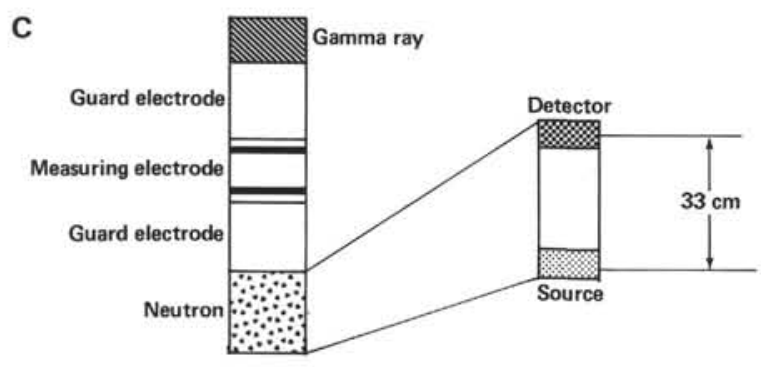

Diameter: $9.2 \mathrm{~cm}$

Length: $4.5 \mathrm{~m}$

Figure 1. A. Combination natural gamma-ray, 2-arm caliper, gamma density, and temperature tool used on first logging run. B. Combination sonic velocity, natural gamma-ray, and 2-arm caliper tool used on second logging run. C. Combination guard resistivity, neutron porosity, and natural gamma-ray tool used on third logging run.

The sonic tool must be centralized in the borehole to give reliable results. The two-arm caliper centralizes the top of the tool; usually, bow springs are used to centralize the bottom, but these were not used in this instance, because they cannot go through the $10-\mathrm{cm}$ restriction in the pipe. Therefore, the bottom portion of the tool (the tool is more than $7 \mathrm{~m}$ long) may not be centralized, especially where the borehole is rough. In the bottom portion of the borehole, the sonic log appeared on first examination to give valid results; but in most of the upper portion of the hole the log appears unusable, probably because of deterioration of the sonic signal, caused by the lack of centralization in the large-diameter, washed-out hole, or by tool malfunction.

\section{Guard Resistivity, Neutron-Thermal-Neutron, and Natural} Gamma-Ray Tools

The third logging run was with a guard resistivity, thermal-neutron, and natural gamma-ray combination tool (Fig. 1C). The tool is free-floating, without centralization or decentralization. Again, the gamma-ray detector is a Geiger-Müller (GM) tube mounted in the upper part of the probe. It appeared to record correctly, but gave a trace almost identical to the neutron log, suggesting that the response re- sulted primarily from an electrical problem, rather than from natural gamma radiation.

The neutron porosity probe is a neutron-thermal-neutron tool that has a $11.1 \times 10^{4} \mathrm{MBq}$ (3-Curie) $\mathrm{AmBe}$ source and a thermal-neutron detector. The source-to-detector separation is $33 \mathrm{~cm}$ (13 in.). If all the pore space (intergranular and fracture) is filled with water, if the size of the borehole is known, and if no neutron absorbers are present in the formation, the porosity of the formation around the borehole can be estimated. The porosity estimate is relative to the limestone porosity of the API calibration test pits. The tool works poorly, with low sensitivity and uncertain calibration, in large-diameter boreholes (greater than $20 \mathrm{~cm}$ or $8 \mathrm{in}$.), particularly if the borehole fluid is seawater, as in the case of DSDP holes. The 33-cm (13-in.) tool available for this leg is much less suitable than the 43-cm (17-in.) tool that had been available previously. Estimates of porosity with this tool are unreliable, and the results from this run were not used.

The guard resistivity $\log$ is one of the few electrical logs that will work satisfactorily when the fluid in the borehole has a high conductivity. The tool is a focused resistivity device with a $25.4-\mathrm{cm}$ (10-in.) measuring electrode between two guard electrodes that focus the current into the formation and not up or down the conductive borehole. Ideally, resistive beds as thin as $25 \mathrm{~cm}$ can be resolved. The device works best when $R_{0} / R_{w}$, the ratio of the formation resistivity to the drilling-fluid resistivity, is $\geq 50$ (Owen and Greer, 1951). Thus, with seawater in the borehole $\left(R_{w}=0.25 \mathrm{ohm}-\mathrm{m}\right)$, the formation resistivity $R_{0}$ should be greater than $10 \mathrm{ohm}-\mathrm{m}$. This condition is satisfied in Hole $395 \mathrm{~A}$, and the log appears to have given good data.

\section{RESULTS FROM CORING}

Hole $395 \mathrm{~A}$ was continuously cored in igneous basement for $571 \mathrm{~m}$. A lithologic column for the section is shown in Figure 2 (Melson, Rabinowitz, et al., 1979b). This column probably contains some inaccuracies because it was reconstructed on the basis of a core recovery of only $19 \%$.

The physical properties data acquired on board for these cores were the $P$-wave velocities at atmospheric pressure, measured both parallel and perpendicular to sea level, the wet bulk density, and the porosity. To facilitate a comparison between the logs and the physical properties of the core, supplementary measurements of electrical resistivity, thermal conductivity and diffusivity, porosity, density, and both compressional- and shearwave velocity as a function of pressure were made on numerous samples from Hole 395A after the completion of Leg 78B (Hyndman et al., this volume). The average porosity measured from these cores was $5.4 \%$. The velocities measured from the cores range from 3.5 to $6.25 \mathrm{~km} / \mathrm{s}$, with most falling between 5.0 and 6.0 $\mathrm{km} / \mathrm{s}$ at a confining pressure of $0.2 \mathrm{kbar}$. The matrix density is $2.95 \mathrm{~g} / \mathrm{cm}^{3}$, and the matrix velocity is commonly about $6.4 \mathrm{~km} / \mathrm{s}(47.6 \mu \mathrm{s} / \mathrm{ft}$.) for basalts of this type (Christensen et al., 1980), although the matrix velocity of the present samples is closer to $6.0 \mathrm{~km} / \mathrm{s}$. These matrix density and velocity values are similar to the values assigned to anhydrite, and are the values used in the log analysis.

Although logging data were acquired using borehole temperature, electrical resistivity, sonic velocity $(\boldsymbol{P}$-wave only), natural gamma-ray, gamma-gamma backscatter density, neuron-thermal-neutron, and caliper tools, only the sonic velocity, resistivity and gamma-gamma backscatter density log data can be compared directly against core measurements. If one assumes that the neutronthermal-neutron log response results primarily from water-saturated porosity, the porosity measurements from 


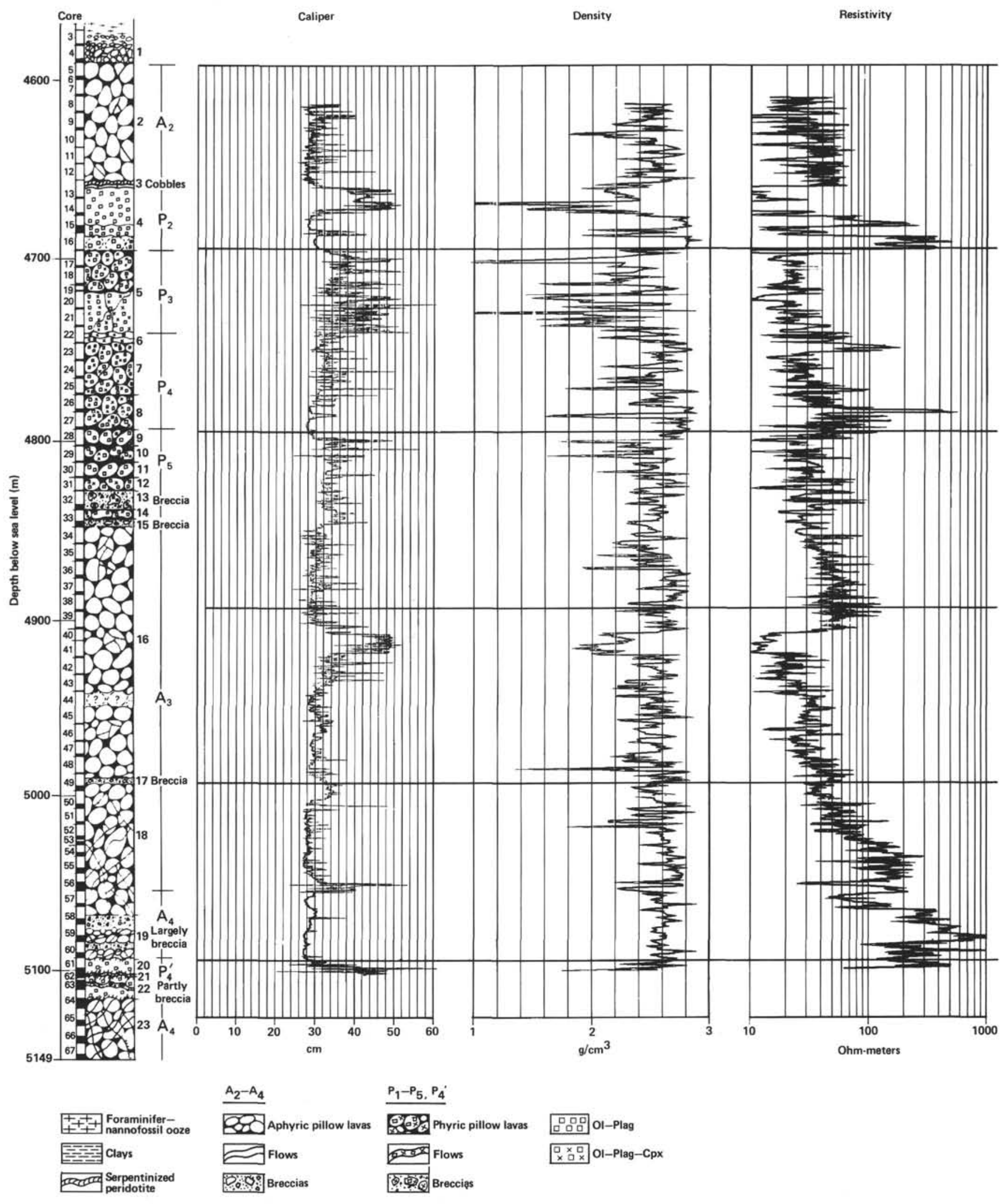

Figure 2. Basement logs obtained on Leg 78B in Hole 395A. Lithology from Melson, Rabinowitz, et al. (1979b). The resistivity log has been corrected for the size of the borehole, assuming that the borehole fluid and the formation fluid had the resistivity of seawater $(0.25$ ohm-m); no correction was made for thin beds. 


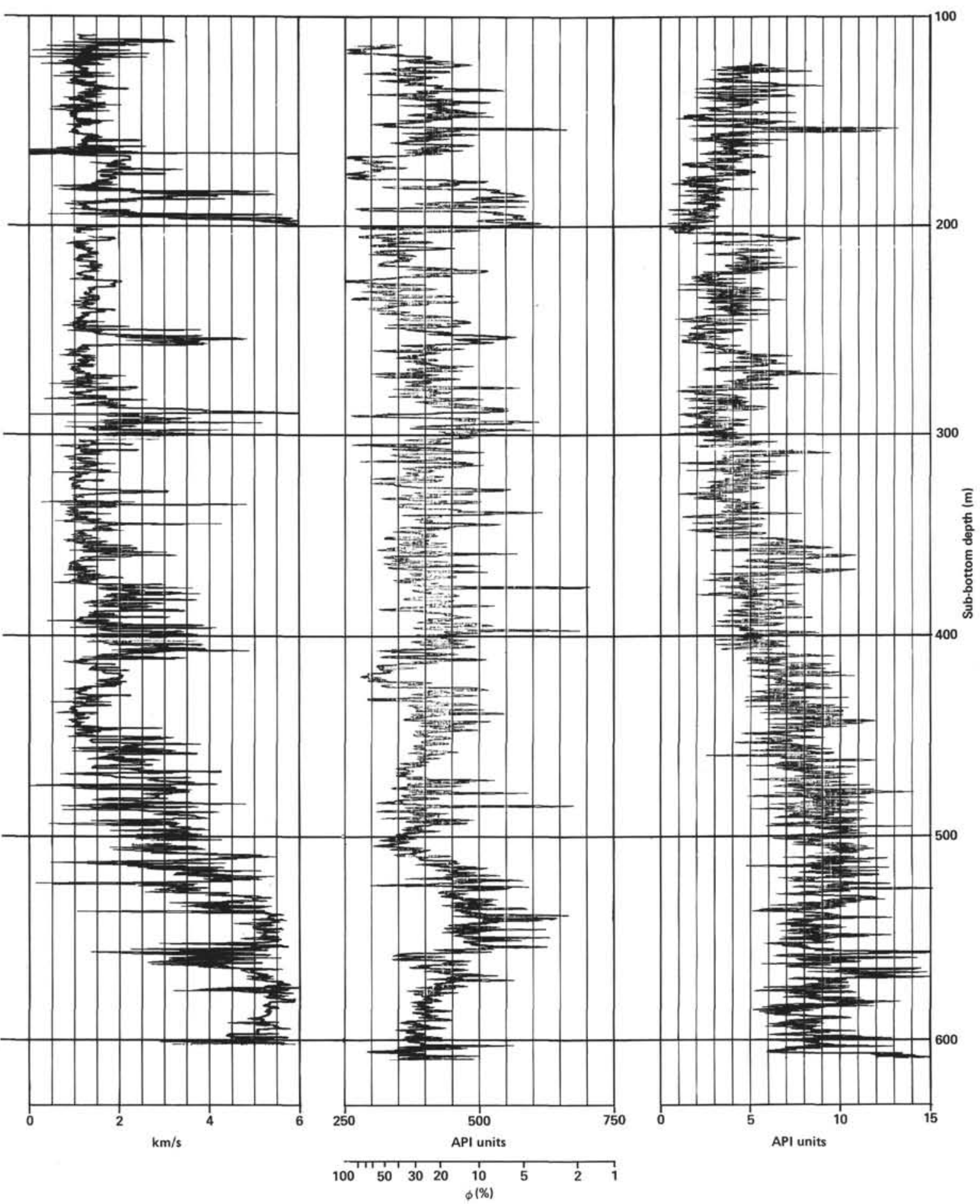

Figure 2. (Continued.) 
the core analysis could be compared as well, but the neutron log data were invalid for this borehole.

\section{LOGGING RESULTS, INTERPRETATION, AND COMPARISON OF DATA}

\section{Logging Quality}

On 21 March and 22 March 1981, a differential temperature log, a combined density, caliper, and gammaray log, a combined sonic and gamma-ray log, and a combined guard (laterolog), neutron, and gamma-ray log were acquired (Fig. 2).

The temperature log (not shown) was acquired going down the borehole. Between 4642 and $4717 \mathrm{~m}$, the log displayed spurious signals that were attributed to computer problems. They were not repeated on later runs. The rest of the log was reasonable, and is discussed in detail by Becker et al. (this volume).

The density log with a two-arm caliper and a natural gamma-ray response was acquired while coming up the borehole. The gamma-ray response of the logging tool used was generally less than 10 API units. This is extremely low, but oceanic basalt holes have commonly exhibited values of less than 20 API, and there is a correlation with the potassium in the core, as shown in Figure 3, so the log is probably valid, although the sensitivity may be low. The density log and the two-arm caliper log are reasonable, although the density values are somewhat low, which is not surprising, considering the size $(>28 \mathrm{~cm})$ and rugosity of the borehole as portrayed by the caliper. The caliper provides calibration and quality control for the density data. Where the caliper tool is fully extended, the borehole is greater than $48 \mathrm{~cm}$ (19 in.), and the density data are suspect. This is also the case where the caliper tool indicates that the borehole is very rough. Where the hole is enlarged or the borehole wall is rough, the density is very low or spikey, and probably does not reflect the density of the formation.

The sonic log with gamma-ray and two-arm caliper responses was obtained next, again while coming up the borehole. The two-arm caliper response was not recorded, because of a malfunction in the recording capability, and the gamma-ray response appears dead. Thus, no usable gamma-ray or caliper data were acquired on this logging run. The sonic portion of this logging tool must be centralized in the borehole to acquired useful traveltime data. The only centralization for the tool was provided by the two-arm caliper located at the upper end of the tool. Generally, a bow spring is located near the bottom so that the tool is centralized at both ends. On this and other DSDP legs the bow spring was removed because of the $10-\mathrm{cm}$ restriction previously discussed. Therefore, the sonic tool was not centralized, and the data were degraded in the rougher portions of the hole. The sonic data acquired from the bottom of the hole to $4967 \mathrm{~m}$ display high velocities and are reasonable in appearance. The data become very noisy and irregular between 4967 and $4917 \mathrm{~m}$. At this time there was a com-
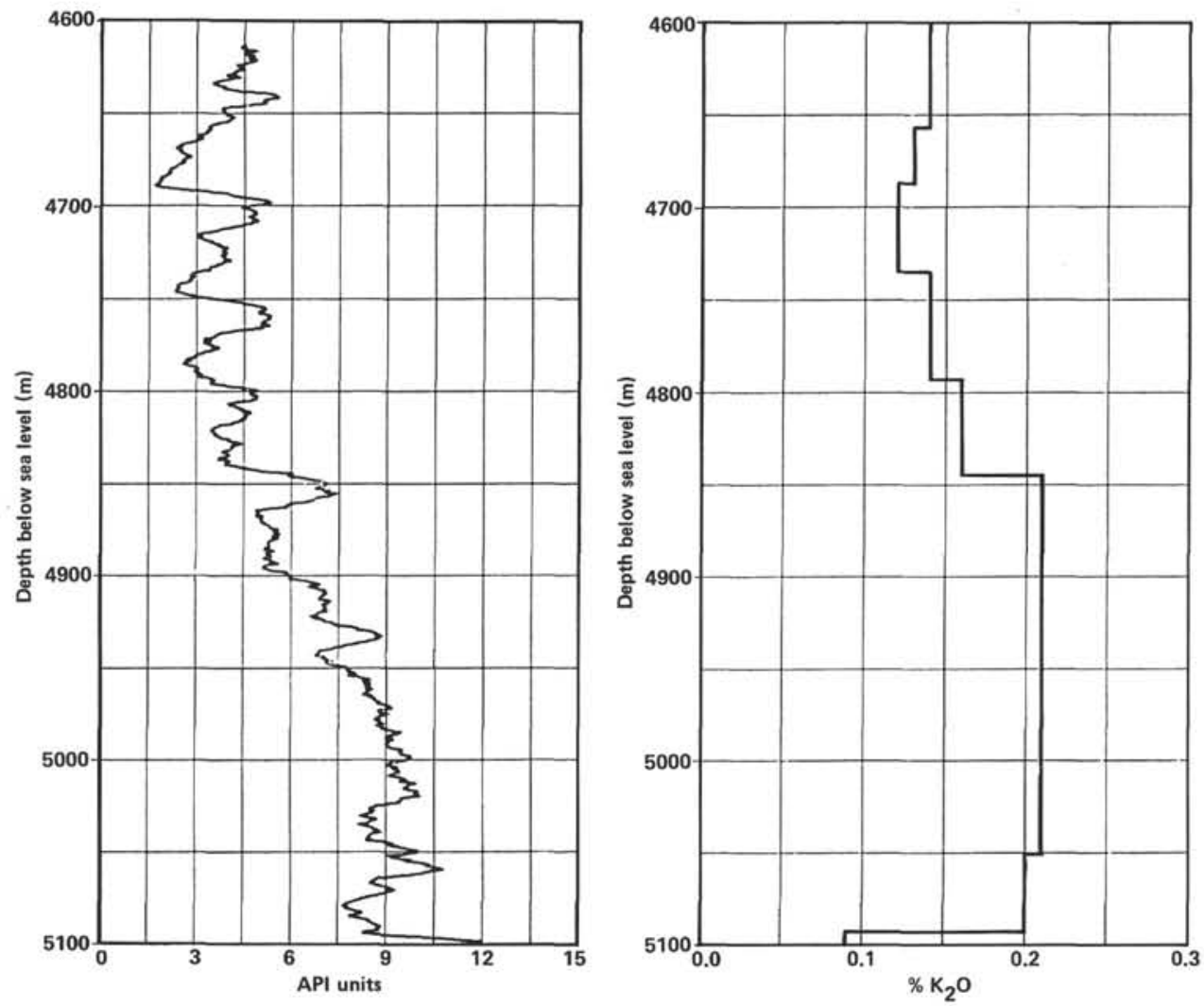

Figure 3. Natural gamma-ray log (left) compared with $\mathrm{K}_{2} \mathrm{O}$ content of basalts from Hole 395A (right). 
puter write error recorded on the console. The log run was stopped, and the logging tool was lowered to a depth of $4927 \mathrm{~m}$, where recording was resumed up the hole. The sonic data recorded from here to the bottom of the casing at $4597 \mathrm{~m}$ are very noisy, and often show velocities lower than that of water. The reason for this could be that (1) the borehole was too rough for the two-arm caliper to centralize the sonic tool; (2) the two-arm caliper stopped working (the two-arm caliper was not checked after logging) and there was no centralization; (3) the sonic tool failed partially in its transmitting or recording function (cycle skipping, incorrect pulse detection); or (4) the sonic data were erroneously recorded (i.e., the computer malfunctioned).

The guard log or deep laterolog with a neutron and a gamma response was obtained next while coming up the borehole. The first attempt to run this log was aborted, owing to a bridle failure. When the run was repeated with a new bridle, data were acquired on the resistivity, neutron, and gamma-ray response for the entire borehole. The gamma-ray and the neutron responses appear qualitatively similar, however, possibly because of an electrical problem. The gamma-ray log obtained on this run will thus be considered no further.

Because of the large borehole size $(>28 \mathrm{~cm})$ and the small spacing between the neutron source and the detector $(33 \mathrm{~cm})$, the tool used is very insensitive to changes in porosity. When it is realized that the borehole fluid was seawater with chlorine, which captures thermal neutrons, the data are one step further removed from reliability. The neutron log obtained reflects little more than changes in lithology and borehole size. The guard log, on the other hand, exhibits high resistivity ( $>500 \mathrm{ohm}-$ $\mathrm{m}$ ) in the more competent basalt flows, suggesting that the data are reasonable and of good quality for most of the hole.

To evaluate the quality of the logs obtained in a more quantitative fashion, all the logs were synchronized and then filtered using a 51-point running average $(0.17 \mathrm{~m}$ between points), or, in the case of the density log, a 17 point average ( $0.5 \mathrm{~m}$ between points). The smoothed logs thus obtained (Fig. 4) were then picked at 10-m intervals and the porosity, density, and velocity data cross-plotted against resistivity (the most reliable data) using Tixier's method (Figs. 5-7). Since many of the logs show a marked change in response in the lowermost $100 \mathrm{~m}$ of the hole, a distinction is made in these plots between data from this interval and data from the rest of the hole.

As expected, the neutron tool did not function properly in any interval of the hole, and no distinction can be made between the tool's behavior in the bottom $100 \mathrm{~m}$ and in the rest of the hole. For any value of resistivity, the tool read erratically and high (Fig. 5).

Although the compressional-wave velocities measured by the sonic tool approach laboratory values in the massive basalt unit near the top of the section (Unit $\mathrm{P}_{2}$ ) and in the lowermost $100 \mathrm{~m}$ of the hole, Figure 6 shows unexpectedly that the tool was reading low and erratically in all but Unit $\mathrm{P}_{2}$ and the bottom $30 \mathrm{~m}$ of the hole.

Like the neutron and sonic tools, the density tool read low throughout the hole. Figure 7 suggests, however, that for high apparent densities $\left(2.4-2.8 \mathrm{~g} / \mathrm{cm}^{3}\right)$ the error is systematic and can be corrected by adding approximately $0.14 \mathrm{~g} / \mathrm{cm}^{3}$ to the measured values.

From this analysis, it is clear that the best logs run in Hole $395 \mathrm{~A}$ are the resistivity, caliper, and possibly the density logs after correction. The remaining logs can only be used qualitatively.

\section{Correlation of Lithology and Log Responses}

The lithology of Hole 395A, described in Table 2 and represented in Figure 2, correlates reasonably well with the filtered and unfiltered log data (caliper, density, neutron, sonic, gamma-ray, and resistivity responses shown in Figs. 2 and 4). The contacts between units $\left(A_{2}, P_{2}\right.$, $\mathrm{P}_{3}, \mathrm{P}_{4}, \mathrm{P}_{5}, \mathrm{~A}_{3}, \mathbf{A}_{4}$, and $\mathrm{P}_{4}$ ) can be shifted slightly up or down by various log correlations. The filtered resistivity data from the guard $\log$ is particularly sensitive to lithology and unit changes (e.g., see the boundary between $A_{3}$ and $A_{4}$ ). The two-arm caliper $\log$ also indicates lithology changes. Areas where the hole is enlarged, washed out, or very rough generally indicate contact zones between flow units. In massive units such as $\mathrm{P}_{2}$, the borehole is usually in gauge, the caliper log is reasonably smooth, and the density, resistivity, sonic, and neutron logs approach laboratory physical property values for basalt. In the pillow basalt units which constitute most of the logged section, however, all the logs showed marked fluctuations, reflecting the presence of pillows, interpillow voids, and washouts, and the density and velocity logs read low while the neutron tool read high. Despite the previously discussed limitations on the quantitative use of these logs, however, an examination of Figure 2 shows that nearly all the major lithologic units defined by the Leg 45 shipboard scientific party (Melson, Rabinowitz, et al., 1979b) can be discerned on the basis of logging data. Not only are the unit boundaries commonly marked by breccias, but the units themselves display a sawtooth pattern in which the velocity, density, and resistivity increase toward the base of each unit as the porosity decreases.

It is also clear in Figure 2 that the section as a whole can be divided into two geophysical units: an upper basement unit characterized by high porosities and extending from 100 to $500 \mathrm{~m}$ sub-bottom; and a lower unit with low porosities extending from 500 to $600 \mathrm{~m}$. Although little more can be said concerning the properties of the upper unit, the situation is considerably better in the lower unit.

If the density log for the lower unit is corrected by adding $0.14 \mathrm{~g} / \mathrm{cm}^{3}$ to the measured values, as suggested by Figure 7, the porosity of the unit can be calculated from the relation

$$
\phi_{D}=\frac{\rho_{B}-\rho_{M}}{\rho_{F}-\rho_{M}}
$$

where $\phi_{D}=$ porosity, $\rho_{B}=$ the density from the logs, $\rho_{M}=$ the matrix density $\left(2.95 \mathrm{~g} / \mathrm{cm}^{3}\right)$, and $\rho_{F}=$ the density of water $\left(1.05 \mathrm{~g} / \mathrm{cm}^{3}\right)$. Setting $\rho_{B}=2.65 \mathrm{~g} / \mathrm{cm}^{3}$ and correcting to $2.79 \mathrm{~g} / \mathrm{cm}^{3}$ for the interval between 


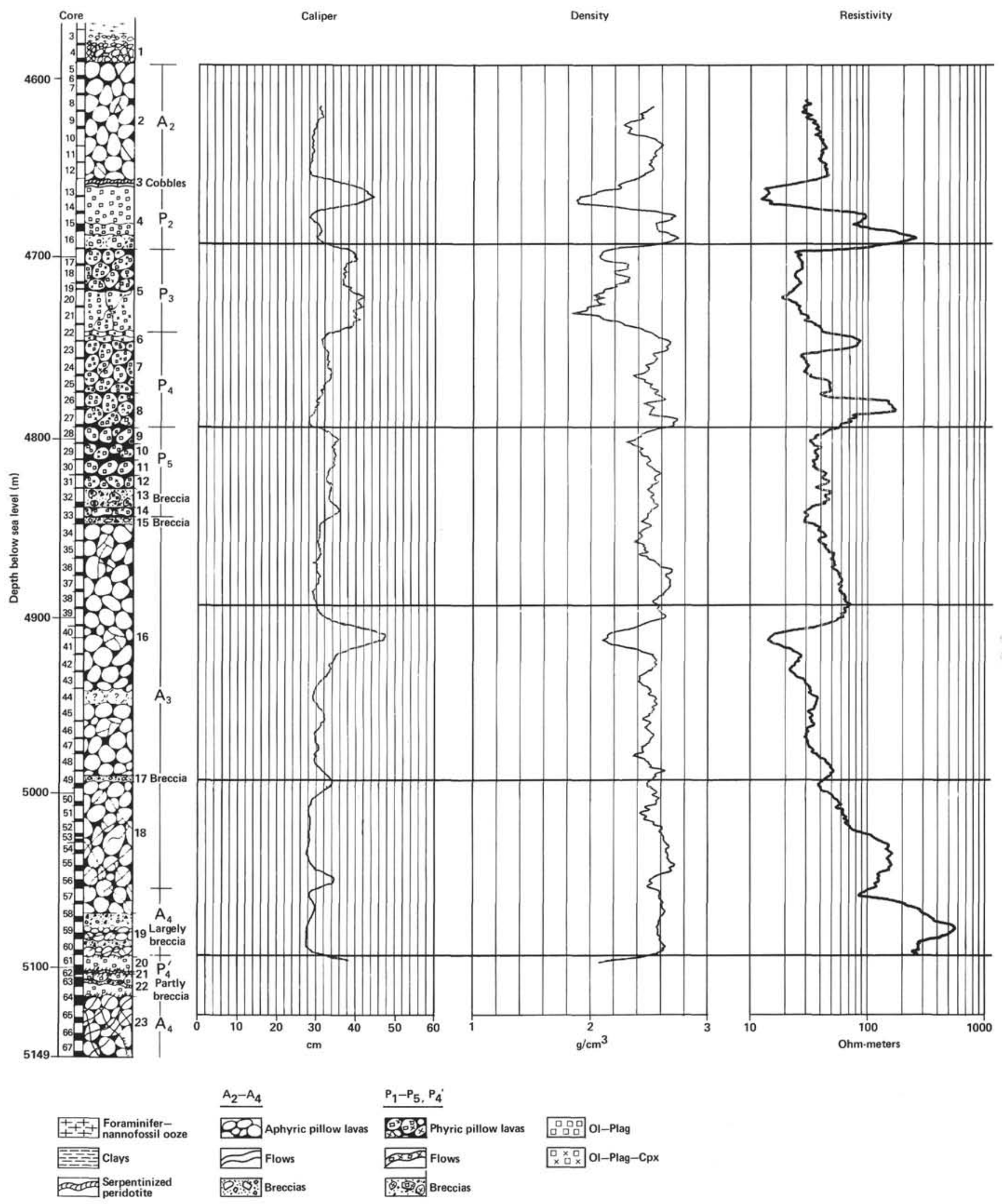

Figure 4. Hole 395A logs filtered using a 51-point running average with a $0.17-\mathrm{m}$. spacing between points (caliper, resistivity, sonic, neutron, and natural-gamma) or a 17 -point filter with a 0.5 -m spacing (density). 


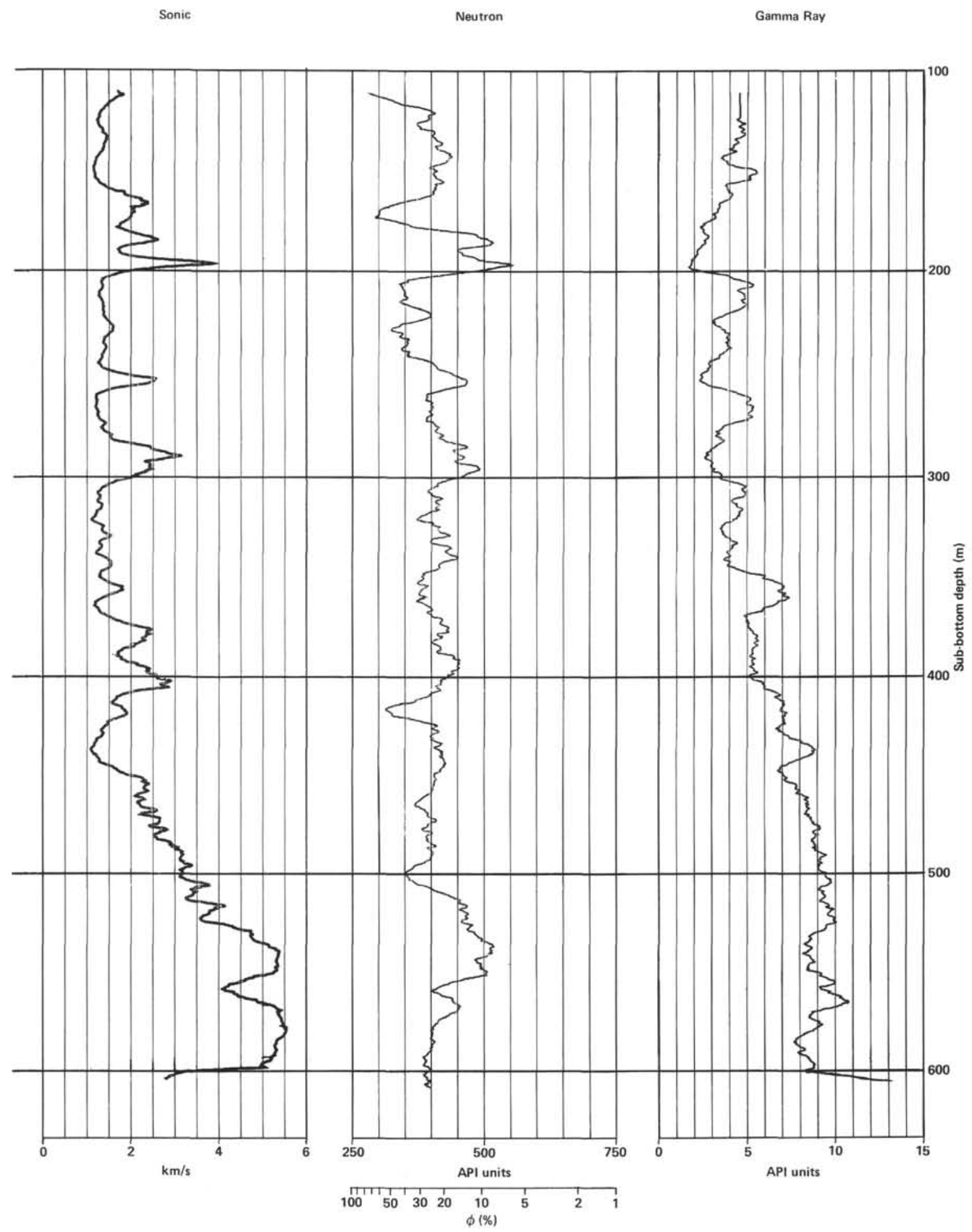

Figure 4. (Continued). 


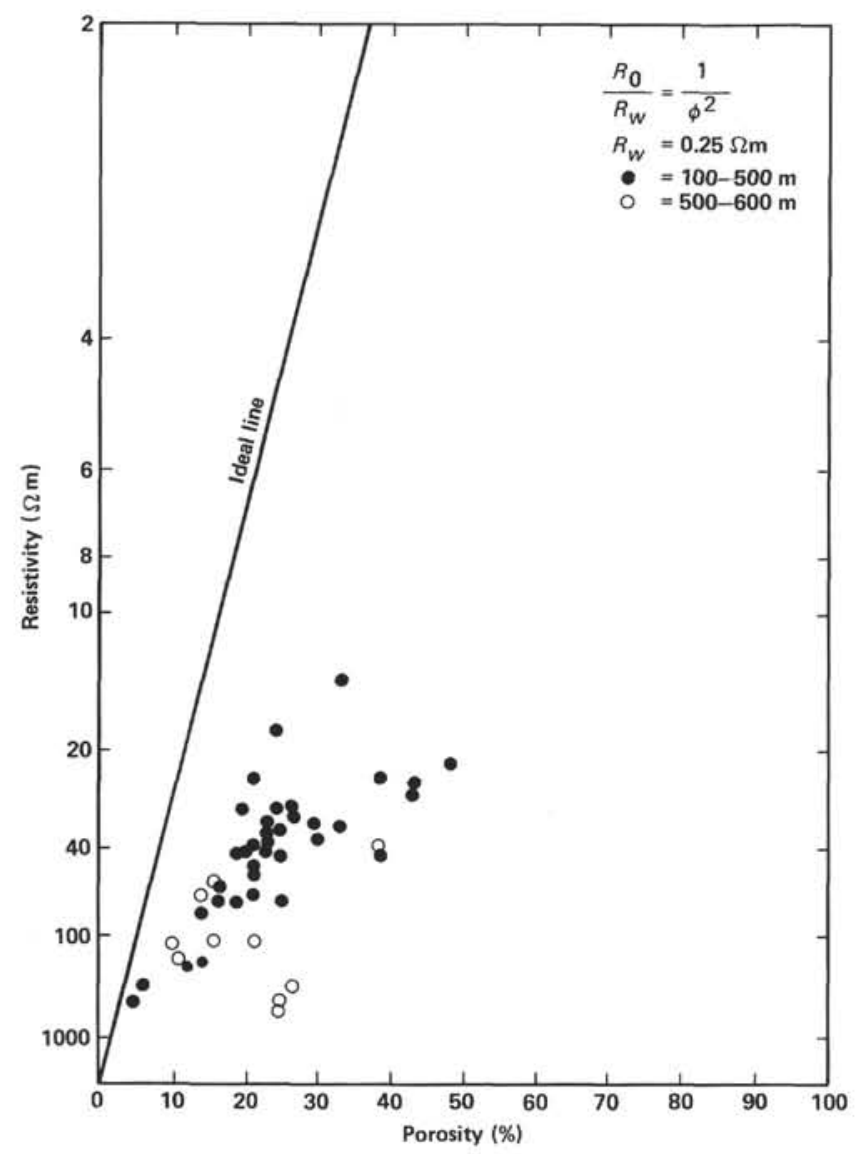

Figure 5. Cross-plot of resistivity vs. neutron pcrosity. $R_{0}$ is the watersaturated formation resistivity, $R_{w}$ is the interstitial-water resistivity, and $\phi$ is porosity.

525 and $550 \mathrm{~m}$ sub-bottom gives a value of $8 \%$ for the formation porosity, $\phi_{\mathrm{D}}$. Since the basalts in this interval have an average porosity of $6 \%$, the formation is about $2 \%$ cracks by volume. Similarly, the interval from 570 to $590 \mathrm{~m}$ sub-bottom $\left(\rho_{B}=2.6 \mathrm{~g} / \mathrm{cm}^{3}\right)$ has a formation porosity of $11 \%$, of which $1 \%$ is cracks by volume.

In like manner, the porosity of the interval from 570 to $590 \mathrm{~m}$ can be calculated from the sonic log from the relation

$$
\phi_{\Delta T}=\frac{\Delta T-\Delta T_{m}}{\Delta T_{f}-\Delta T_{m}},
$$

where $\phi_{\Delta T}=$ porosity, $\Delta T=$ the travel time from the logs, $\Delta T_{m}=$ the matrix travel time $(51 \mu \mathrm{s} / \mathrm{ft}$. or $6.0 \mathrm{~km} / \mathrm{s}$, from Melson, Rabinowitz, et al., 1979a), and $\Delta T_{F}=$ the fluid travel time $(203.3 \mu \mathrm{s} / \mathrm{ft}$. or $1.5 \mathrm{~km} / \mathrm{s})$. Setting $\Delta T=58 \mu \mathrm{s} / \mathrm{ft}$. $(5.3 \mathrm{~km} / \mathrm{s})$ gives an average formation porosity of $5 \%$ for this interval.

Finally, from a comparison of the resistivity data and the porosities determined from the velocity log, it is possible to determine the degree to which the porosity is interconnected in this interval by using Archie's Law (1942):

$$
F=\frac{R_{0}}{R_{w}} a \phi^{-m}
$$

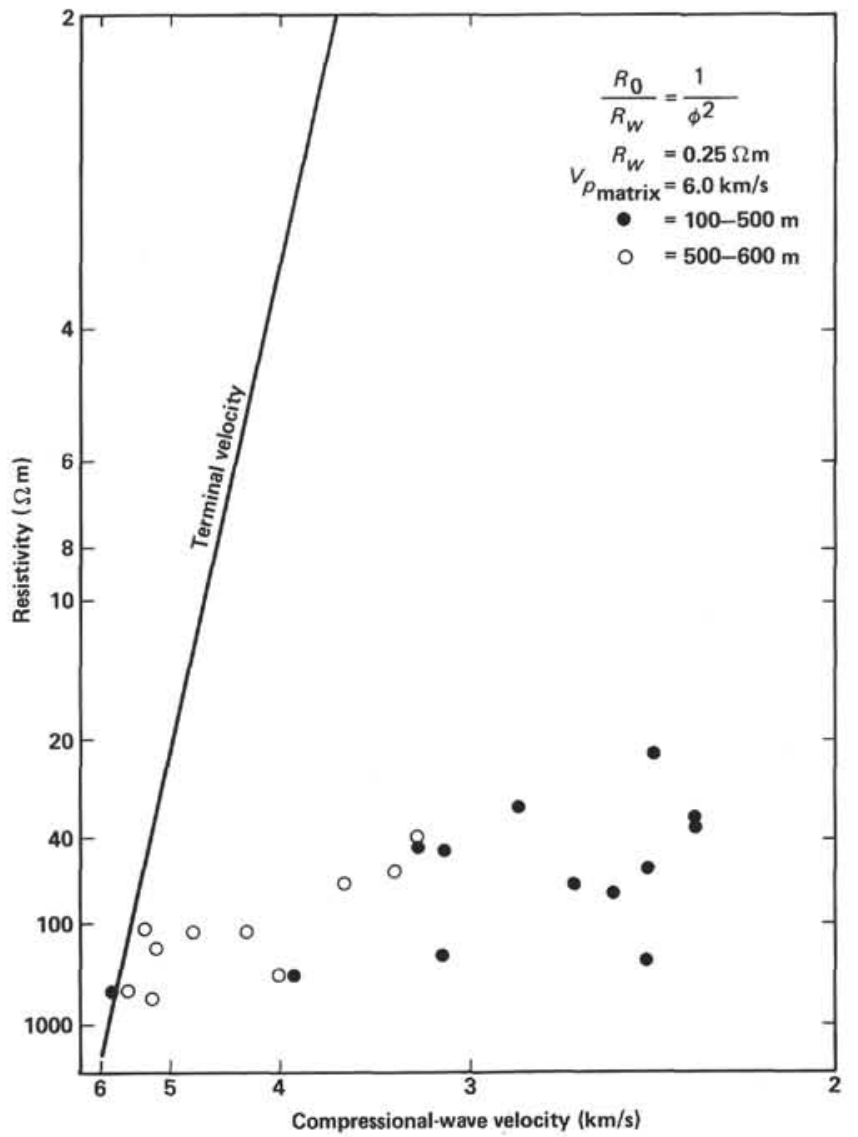

Figure 6. Cross-plot of resistivity vs. compressional-wave velocity. $\boldsymbol{R}_{0}$ is the water-saturated formation resistivity, $R_{w}$ is the interstitialwater resistivity, and $\phi$ is porosity. The matrix velocity, $6.0 \mathrm{~km} / \mathrm{s}$ for the Hole 395A basalts, is from Melson, Rabinowitz, et al. (1979a).

which can be written as

$$
\ln R_{0}=\ln \left(a R_{w}\right)-m \ln \phi
$$

where $F=$ the formation factor, $R_{0}=$ the borehole-corrected formation resistivity ( $100 \%$ water saturated), $R_{w}$ $=$ the resistivity of seawater in the formation $(0.25 \mathrm{ohm}$ $\mathrm{m}), a$ and $m$ are constants, and $\phi=$ porosity. From a plot of resistivity vs. porosity (determined from the velocity using equation 2 ), the exponent $m=2.2$, which indicates that the porosity is very poorly connected and the permeability is low in the bottom of the hole (Fig. 8 ). This is consistent with the low permeabilities (2-9 $\mu$ darcies) measured in this interval on Leg 78B using a packer (Hickman et al., this volume) and with the porosity-permeability relationships discussed by Kozeny (1927) and Timur (1968), in which

$$
K=\frac{A \phi^{B}}{S_{w r}^{C}}
$$

where $K=$ the single-phase permeability (in darcies), $\phi$ $=$ porosity, $S_{w r}=$ residual (irreducible) water saturation, and $A, B$, and $C$ are constants. For the case in which $S_{w r}$ approaches $100 \%$ (as here), this reduces to

$$
K=A \phi^{B}
$$




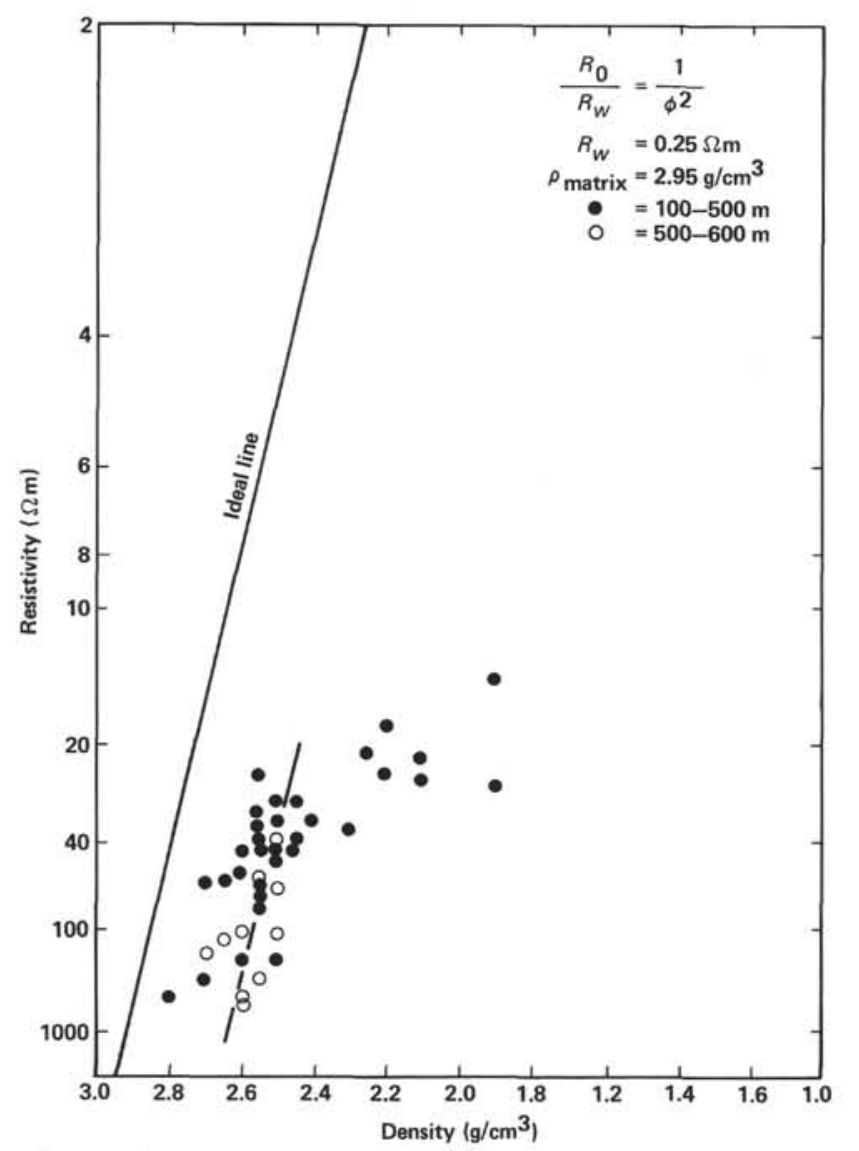

Figure 7. Cross-plot of resistivity vs. density. $R_{0}$ is the water-saturated formation resistivity, $R_{w}$ is the interstitial-water resistivity, and $\phi$ is porosity.

\section{Conclusions}

Reasonable logging data were acquired over selected intervals in Hole 395A using density, natural-gamma, temperature, resistivity, caliper, and sonic velocity tools. Neutron logs were also obtained, but the poor quality of the data only allows the logs to be used qualitatively. The logs correlate well with the lithologic column derived on Leg 45 from coring, as shown in Figure 2. In particular, the boundaries between the lithologic units discerned by the Leg 45 shipboard scientific party are often marked by breccias, and each unit tends to become less porous with depth (and thus to have increasing velocity, density, and resistivity with depth).

One of the most striking features of the Hole 395A logs, however, is the clear division of the section logged into two distinct geophysical units. The upper unit from 100 to $500 \mathrm{~m}$ sub-bottom (i.e., the upper $400 \mathrm{~m}$ of the basement) is highly porous, with a low average velocity, resistivity, and density. The lower unit, between 500 and $600 \mathrm{~m}$, displays a low average crack porosity $(1-2 \%)$, high resistivities (50-600 ohm-m, with occasional values as high as $1000 \mathrm{ohm}-\mathrm{m}$ ), and velocities which are among the highest recorded to date by logging in the oceanic basement $(4.8-5.5 \mathrm{~km} / \mathrm{s}$, with occasional values as high as $6.0 \mathrm{~km} / \mathrm{s}$ ). Cross-plots of resistivity vs. porosity de-

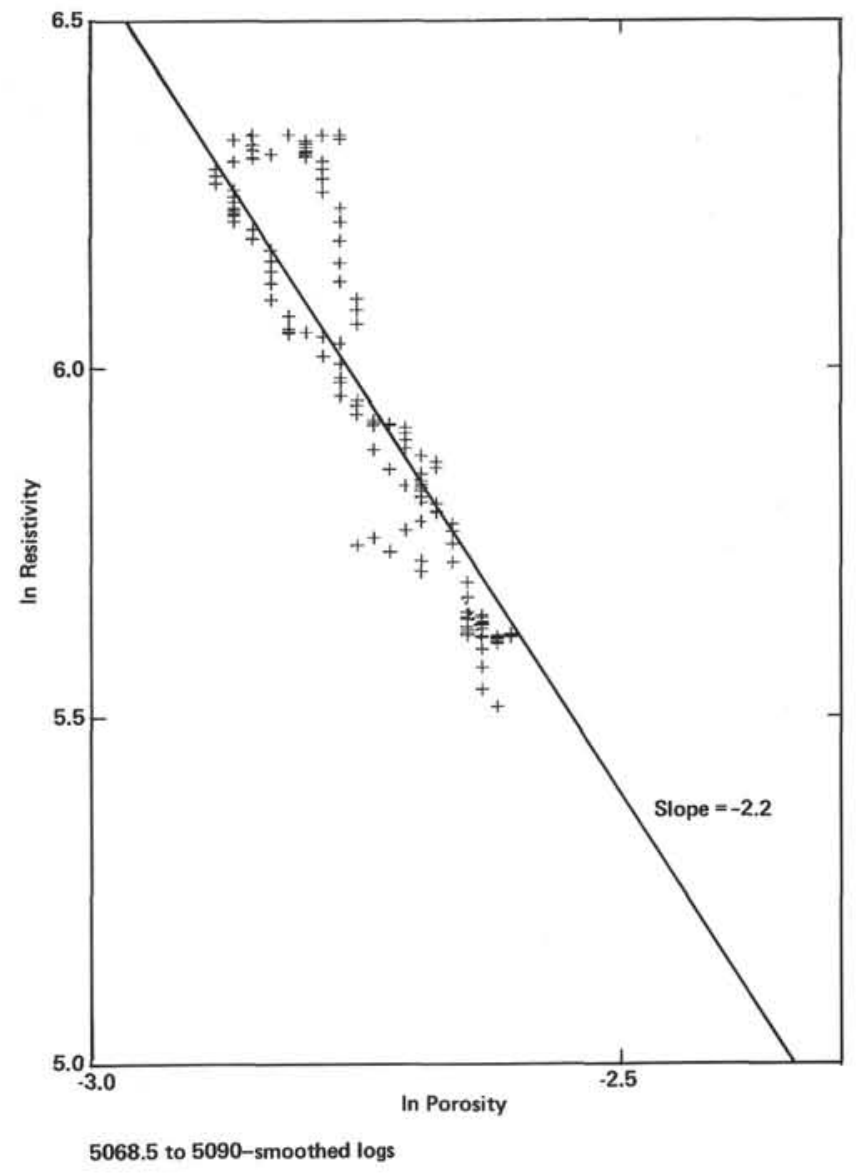

Figure 8. Cross-plot of resistivity vs. porosity determined from velocity for the interval 580 to $600 \mathrm{~m}$ sub-bottom.

rived from velocity at the bottom of the hole give a value for the exponent $m$ in Archie's Law of 2.2, which is consistent with the extremely low permeabilities measured in this interval by Hickman et al. (this volume). Since the lower unit is characterized by a marked increase in alteration products (Melson, Rabinowitz, et al., 1979b) and behaves as if it were sealed, we conclude that Hole 395A pierced a major geophysical boundary in the crust.

\section{ACKNOWLEDGMENTS}

We wish to thank the crew and staff of the Glomar Challenger for their assistance during the logging operation on Leg 78B. We also wish to express our appreciation to Gearhart Industries for their assistance in processing the data, and to Bruce Cloyd for running the logs.

\section{REFERENCES}

Archie, G. E., 1942. The electrical resistivity $\log$ as an aid in determining some reservoir characteristics. Petrol. Tech., 5:54-62.

Becker, K., Von Herzen, R. P., Francis, T. J. G., Anderson, R. N., Honnorez, J., Adamson, A. C., Alt, J. C., Emmermann, R., Kempton, P. D., Kinoshita, H., Laverne, C., Mottl, M. J., and Newmark, R. L., 1982. In situ electrical resistivity and bulk porosity of the oceanic crust Costa Rica Rift, Nature, 300:594-598.

Boyce, R. E., 1980. Determination of the relationships of electrical resistivity, sound velocity and density/porosity of sediment and rock by laboratory techniques and well logs from Deep Sea Drilling Project Sites $\mathbf{4 1 5}$ and 416 off the coast of Morocco. In Lancelot, Y., Winterer, E. L., et al., Init. Repts. DSDP, 50: Washington (U.S. Govt. Printing Office), 305-318. 
1981. Electrical resistivity, sound velocity, thermal conductivity, density-porosity, and temperature determined by laboratory techniques and well logs: Site 462 in the Nauru Basin of the Pacific Ocean. In Larson, R. L., Schlanger, S. O., et al., Init. Repts. DSDP, 61: Washington (U.S. Govt. Printing Office), 743-762.

Cann, J. R., and Von Herzen, R. P., 1983. Downhole logs at Deep Sea Drilling Project Sites 501, 504 and 505, near the Costa Rica Rift. In Cann, J. R., Langseth, M. G., Honnorez, J., Von Herzen, R. P., White, S. M., et al., Init. Repts. DSDP, 69: Washington (U.S. Govt. Printing Office), 281-300.

Christensen, N. I., Blair, S. C., Wilkens, R. H., and Salisbury, M. H., 1980. Compressional wave velocities, densities and porosities of basalts from Holes 417A, 417D and 418A, DSDP Legs 51-53. In Donnelly, T., Francheteau, J., Bryan, W., Robinson, P., Flower, M., Salisbury, M., et al., Init. Repts. DSDP, 51, 52, 53, Pt. 2: Washington (U.S. Govt. Printing Office), 1467-1472.

Christensen, N. I., and Salisbury, M. H., 1975. Structure and constitution of the lower oceanic crust. Rev. Geophys. and Space Phys., 13:57-86.

Curray, J. R., Moore, D. G., et al., 1982. Init. Repts. DSDP, 64: Washington (U.S. Govt. Printing Office).

Hamano, Y., 1980. Physical properties of basalts from Holes 417D and 418A. In Donnelly, T., Francheteau, J., Bryan, W., Robinson, P., Flower, M., Salisbury, M., et al., Init. Repts. DSDP, 51, 52, 53, Pt. 2: Washington (U.S. Govt. Printing Office), 1457-1466.

Hussong, D. M., Fryer, P. B., Tuthill, J. D., and Wipperman, L. K., 1979. The geological and geophysical setting near DSDP Site 395, North Atlantic Ocean. In Melson, W. G., Rabinowitz, P. D., et al., Init. Repts. DSDP, 45: Washington (U.S. Govt. Printing Office), 23-37.

Hyndman, R. D., and Drury, M. J., 1976. The physical properties of oceanic basement rocks from deep drilling on the Mid-Atlantic Ridge. J. Geophys. Res., 81:4042-4052.

Johnson, D. M., 1980. Fluid permeability of oceanic basalts. In Donnelly, T., Francheteau, J., Bryan, W., Robinson, P., Flower, M., Salisbury, M., et al., Init. Repts. DSDP, 51, 52, 53 Pt. 2: Washington (U.S. Govt. Printing Office), 1473-1478.

Kasahara, J., Hussong, D. M., and Sutton, G. H., 1980. A seismic study using ocean bottom seismometers near the Mid-Atlantic Ridge at $23^{\circ}$ N. Mar. Geol., 35:199-218.

Kirkpatrick, R. J., 1979. Results of downhole geophysical logging Hole 396B, DSDP Leg 46. In Dmitriev, L., Heirtzler, J., et al., Init. Repts. DSDP, 46: Washington (U.S. Govt. Printing Office), 401-408.

Kozeny, J., 1927. Uber kopillare leitung de- wassers im boden. Sitzber. Akad. Wiss. Wien, Math.-Natur. Kl., 136(Abt. IIa):271-306.
Mathews, M., and LaDelfe, C., 1981. Log Comparison and Quantification. CWLS, 8th Formation Evaluation Symposium Transactions, Paper I.

Melson, W. G., Rabinowitz, P. D., et al., 1979a. Init. Repts. DSDP, 45: Washington (U.S. Govt. Printing Office). 1979b. Site 395: $23^{\circ} \mathrm{N}$, Mid-Atlantic Ridge. In Melson, W. G., Rabinowitz, P. D., et al., Init. Repts. DSDP, 45: Washington (U.S. Govt. Printing Office), 131-264.

Montadert, L., Roberts, D. G., et al., 1979. Site 402/Hole 402A. In Montadert, L., Roberts, D. G., et al., Init. Repts. DSDP, 48: Washington (U.S. Govt. Printing Office), 125-164.

Owen, J. E., and Greer, W. J., 1951. The guard electrode logging system. Petrol. Trans. AIME, 192:347-356.

Salisbury, M. H., 1983. Basement logs from the mouth of the Gulf of California, Deep Sea Drilling Project Leg 65. In Lewis, B. T. R., Robinson, P., et al., Init. Repts. DSDP, 65: Washington (U.S. Govt. Printing Office), 329-342.

Salisbury, M. H., Donnelly, T. W., and Francheteau, J., 1980. Geophysical logging in Deep Sea Drilling Project Hole 417D. In Donnelly, T., Francheteau, J., Bryan, W., Robinson, P., Flower, M., Salisbury, M., et al., Init. Repts. DSDP, 51, 52, 53, Pt. 1: Washington (U.S. Govt. Printing Office), 705-713.

Salisbury, M. H., Stephen, R., Christensen, N. I., Francheteau, J., Hamano, Y., Hobart, M., and Johnson, D., 1980. The physical state of Cretaceous oceanic crust from the results of logging, laboratory studies, and the oblique seismic experiment at Deep Sea Drilling Project Sites 417 and 418. In Donnelly, T., Francheteau, J., Bryan, W., Robinson, P., Flower, M., Salisbury, M., et al., Init. Repts. DSDP, 51, 52, 53, Pt. 2: Washington (U.S. Govt. Printing Office), 1579-1597.

Schreiber, E., and Rabinowitz, P. D., 1979. Acoustic wave velocity measurements of oceanic crustal samples-DSDP Leg 45. In Melson, W. G., Rabinowitz, P. D., et al., Init. Repts. DSDP, 45: Washington (U.S. Govt. Printing Office), 383-386.

Stone, D. G., and Evans, H. B., 1980. Extrapolating logs run in exploration or development wells using seismic data. SPWLA Twenty-First Annual Logging Symposium Transactions, paper KK.

Timur, A., 1968. An investigation of permeability, porosity, and residual water saturation relationship for sandstone reservoirs. $\log$ Anal., 9:8-17.

Yeats, R. S., Haq, B. U., et al., 1981. Init. Repts. DSDP, 63: Washington (U.S. Govt. Printing Office).

Date of Initial Receipt: March 10, 1983

Date of Acceptance: October 10, 1983 